\title{
Traffic Policy Model for Bandar Lampung City as Hinterland in Indonesia
}

\author{
Bambang Hartono \\ Law Faculty of Universitas Bandar Lampung \\ Recca Ayu Hapsari* \\ Law Faculty of Universitas Bandar Lampung
}

\begin{abstract}
Bandar Lampung City has good prospect to be developed into a big city on regional, national, and international scale. The potential of the city comes up due to its ability in supporting the surrounding area (hinterland) that contributes to the growth and development of Bandar Lampung. The purpose and direction of policy with human social value is a policy based on community participation and awareness. The traffic policy model is viewed in a legal and social perspective, referred to the idea of a policy form based on social values of society that refer to principles (participatory, useful, efficient and effective, balanced, integrated, independent, sustainable, and transparent). This research uses qualitative analysis technique.It is to examine the policy related traffic that become the object of research then projected to the standard of applicable legal/regulatory norms. Then it is interpreted by theory (theoretical interpretation) and drawn the generalization as an ideal formula (ius constitutum).The conclusion is the Policy to anticipate traffic congestion. From the City Government of Bandar Lampung, it has been poured into a work program based on integrated factors, organized, systematic and based on the interests, justice and welfare of the people, providing space for public involvement in the participation and participation of all components of the wider community.
\end{abstract}

Keywords: Policy Model; Traffic; Hinterland; Bandar Lampung City; Qualitative Analysis

DOI: $10.7176 / \mathrm{JLPG} / 89-16$

Publication date:September $30^{\text {th }} 2019$

\section{Introduction}

The Indonesian nation is a pluralist society. This community is in the process of leading a civil society that is characterized by upholding/respecting the values of democracy, transparency, rule of law, protection of human rights and the environment. Thus the law-abiding society is a characteristic of civil society as well as the realization of the rule of law. They are described as a society that accepts the law as a rule, provision, agreement with full awareness and sincerity and applies as a guideline in their daily attitudes and behavior. The implementation of efforts to increase legal awareness for the public regarding traffic policy is to put into practice a policy model that is in accordance with the characteristics of the city.

The policy to deal with traffic congestion in Bandar Lampung City at this time is Law Number 23 Year 2014 concerning Regional Government Article 10 paragraph (1) and (2) that the regional government carries out government affairs which are its authority, except for matters which become central government affairs. In carrying out its government affairs, the regional government carries out the widest possible autonomy to regulate and manage its own government affairs based on the principle of autonomy and the task of division.

In the space of just a few decades, urban areas across the worldin both developed and developing countries have become increasingly automobile-dominated and lesssustainable. In developing countries in particular, cities have experienced a rapid growth in transport-related challenges, including pollution, congestion, accidents, public transport decline, environmental degradation, climate change, energy depletion, visual intrusion, and lack of accessibility for the urban poor. In more developed countries, particularly in Northern Europe, some cities have witnessed a trend of reclaiming urban space from the automobile and prohibiting cars from major parts of downtown areas and/or confining them in other ways.

Traffic congestion problem is the main thing for the citizens of big cities in almost entire homeland. Example in Pakistan, to reduce road congestion, Pakistan must revise national transportation policy and split traffic volume into different modes (Nazir e, et al, 2016). This problem is also felt by all residents of the city of Bandar Lampung or other districts / cities in the province of Lampung. The transportation problems faced by the City of Bandar Lampung today are traffic jams that occur on the main road segments within the downtown area. Besides that, also the cause of congestion that often occurs in big cities is that traders and parking vehicles are not well organized, causing vehicles to use sidewalks and the edge of the road to park. Disruption of pedestrian facilities caused by vehicles parked on the sidewalks and the lack of crossing facilities caused undisciplined pedestrians to cross the road. Non-motorized vehicles that mingle with motorized vehicles contribute to considerable side barriers. The indiscipline of the drivers of public transport and motorbike riders caused chaos in the flow of vehicles. The problem of the minimum width and length of the main road sections in the downtown 
area causes the capacity of the road to be very limited. Another traffic problem is traffic density caused by the high volume of traffic flow on the main road segments. Traffic congestion in Bandar Lampung City occurs on the main road segments in the CBD area (Central Business District), especially during rush hour.

Traffic congestion in the center of Bandar Lampung City forms a systemic pattern. The traffic jam system is formed because the congestion area is interrelated. The connection of the congestion area is formed by the pattern of movement of vehicles on the existing road network system (Dedi Firdaus, 2006). The central road network system of Bandar Lampung City was formed by building use that had been built first. The position of shops and other buildings that are on the side of the road body greatly affects the pattern of the formation and development of the next road network system. The width of the section of the road which is limited by the building on the left and right of the road limits the capacity of the volume of the flow of vehicle traffic.

Regarding the function of the City of Bandar Lampung as a transshipment point for various modes of transportation, Bandar Lampung City is prepared as a hinterland for the surrounding cities. In its preparation it was mentioned in the plan to develop a regional transportation system such as the planned construction of the Sunda Strait Bridge connecting Java and Sumatra to facilitate the flow of passengers and goods between the islands of Java and Sumatra.The Panjang Port complements the intermodal transportation system for all Lampung and Southern Sumatra Provinces. The idea is that the Trans Sumatra railway network is an alternative means of intermodal movement. The city is a meeting point between the middle and east crossing of Sumatra. Vehicles from other regions on the island of Sumatra must pass through Bandar Lampung when heading to Java. With its geographically strategic location, the availability of adequate access and supporting transportation routes and the complete supporting facilities make the city of Bandar Lampung a potential as a hinterland area.

In developing countries, where new road construction is often seen as a yardstick of modernization, government has often allocated public expenditures in favor of new road construction at the expense of other urban transport investments and the maintenance of existing infrastructure. In terms of road investment, evidence to date suggests that developing cities need to focus their resources on existing road maintenance rather than new road construction (Dorina Pojani; Dominic Stead, 2015).

However, the imbalance between the increase in infrastructure and the growth in the number of vehicles will cause urban transportation problems in Bandar Lampung to become more complex. Other problems with urban transportation include determining the type and modes of public transportation, network patterns, transport route permits, parking policies, and installing traffic signs. The point in this discussion is related to policies that will be effectively implemented and whether the policy has been adjusted to the needs of the community.

\section{Bandar Lampung as Hinterland in Indonesia}

The hinterland region is usually referred to as the satellite city. Basically the word has the same meaning, namely small cities around big cities that have similarities in performance patterns but in a smaller scope. In the hinterland area there are still economic, educational, health or other facilities but on a small scale; not as complex as in a big city or city center. Economically, the hinterland region can run the economy independently even though there are some goods and services that are still dependent on big cities, but broadly speaking, the hinterland area or satellite city can fulfill city facilities that can ultimately provide jobs for the community or residents suburban.In other words, according to (Yunus, 2005) it can be revealed that the hinterland region also functions as a recipient of labor because it has developed urban socio-economic functions which also act as suppliers of commodities to other places.

The existence of a center for economic growth has implications for economic activities that occur in the community, namely, how the production of these centers of growth can be used to support the implementation of economic activities in the area around the growth center (hinterland). On the other hand, the production of the hinterland area is also used to support economic activities at the center of growth. Therefore, policies taken in these places become generators to support the economic activities of the surrounding area (Imelda, 2013).

Bandar Lampung City is the capital of Lampung Province which has experienced rapid pace of regional development and is also a strategic area. This is due to its position as a regional activity center in the national spatial plan. Besides that, Bandar Lampung is also a transit area/city for users of inter-island transportation services, namely Java and Sumatra. Bandar Lampung City is the gateway to the island of Sumatra. The city located in the southwest of Sumatra Island has a very favorable geographical position. It is located on the tip of Sumatra Island adjacent to DKI Jakarta which is the center of the country's economy. The city is a meeting point between the middle and east crossing of Sumatra.Vehicles from other regions on the island of Sumatra must pass through Bandar Lampung when heading to Java. In general, these vehicles transit at Rajabasa terminal. This area is also a center for distribution services and hinterland for the surrounding area, such as Southern Sumatra; Banten and DKI. Thus the intensity of the flow of people (labor), goods, and services in this region is quite high. This phenomenon in turn has made this region has developed rapidly, which among others is marked by the development of population, relatively high economic growth rates and the development of increasing accessibility. 
As a center of activity in Lampung Province, around $12.4 \%$ of the population of Lampung Province is in the city of Bandar Lampung. Various services for a wider area are provided by the City of Bandar Lampung, namely in the fields of government, commerce, financial services, education, and so on. The role as the center of growth is supported by an accessibility improvement plan to and from Bandar Lampung City (Bandar Lampung City Government, 2018).

In realizing the achievement of the central growth system mechanism in Lampung Province, there have been three Sumatra cross lines, namely:

1. Central lane, starting from Bakauheni Port - Bandar Lampung - Kotabumi and then to Muara Enim.

2. West Cross, starting from Bandar Lampung - Kota Agung - Liwa and then to Bengkulu Province.

3. East Crossing, from Bakauheni Port - Menggala - Kayu Agung and so on to Palembang.

All of them cross Bandar Lampung. In addition, Bandar Lampung is ready to function as a transshipment point for various modes of transportation. This is supported by various development plans in the regional transportation system. The trend of development shows the process of relocating economic activities from the western part of Java to Lampung. In fact, for some sectors, the policy was determined to make Lampung a national production base. This makes Bandar Lampung potential as a distribution center for goods and services for the Southern Sumatra region.

Bandar Lampung City is an area of $197.22 \mathrm{~km}^{2}$ which is divided into 19 sub-districts and 98 urban villages with a population of 881.801 people (based on the 2015 census), population density of around 8,142 people / $\mathrm{km}^{2}$. Dense population can also cause congestion in the city center due to population activities. Population, Area, and Population Density per District in Bandar Lampung City In 2011-2015 based on the results of the population census updated by the Bandar Lampung City Central Bureau of Statistics on January 10, 2017 are listed in the following table.

Table. 1 Total Population, Territory and Population Density Data Source: Central Statistics Agency of Bandar Lampung

\begin{tabular}{|c|l|c|c|c|}
\hline No & \multicolumn{1}{|c|}{ Sub-district } & Total Population & Territory & Population Density \\
\hline 1 & Western Teluk Betung & 29.799 & 11,02 & 2.704 \\
\hline 2 & EasternTeluk Betung & 41.645 & 14,83 & 2.808 \\
\hline 3 & SouthernTeluk Betung & 39.353 & 3,79 & 10.383 \\
\hline 4 & Bumi Waras & 56.742 & 3,75 & 15.131 \\
\hline 5 & Panjang & 74.506 & 15,75 & 4.731 \\
\hline 6 & Eastern Tanjung Karang & 37.108 & 2,03 & 18.280 \\
\hline 7 & Kedamaian & 52.592 & 8,21 & 6.406 \\
\hline 8 & NorthernTeluk Betung & 50.593 & 4,33 & 11.684 \\
\hline 9 & The Center of Tanjung Karang & 51.126 & 4,05 & 12.624 \\
\hline 10 & Enggal & 28.084 & 3,49 & 8.047 \\
\hline 11 & WesternTanjung Karang & 54.710 & 14,99 & 3.650 \\
\hline 12 & Kemiling & 65.637 & 24,24 & 2.708 \\
\hline 13 & Langkapura & 33.944 & 6,12 & 5.546 \\
\hline 14 & Kedaton & 49.055 & 4,79 & 10.241 \\
\hline 15 & Rajabasa & 48.027 & 13,53 & 3.550 \\
\hline 16 & Tanjung Senang & 45.775 & 10,63 & 4.306 \\
\hline 17 & Labuhan Ratu & 44.843 & 7,97 & 5.626 \\
\hline 18 & Sukarame & 56.921 & 14,75 & 3.859 \\
\hline 19 & Sukabumi & 57.334 & 23,6 & 2.429 \\
\hline
\end{tabular}

In relation to the geographical and demographic conditions of Bandar Lampung City, this led Bandar Lampung to seize the opportunity to become one of the growth centers that play a role in the IMS-GT regional economic system and become part of the largest corridor of Indonesia's economic activity, namely South Sumatra - Lampung - Banten - Jabotabek. In the constellation of the economic space, Bandar Lampung has the opportunity to fill economic functions selectively and competitively, especially in the existing system of growth centers. Strategic access improvement for the flow of goods is through the development of the Panjang Port. This port, which is expected to be the largest export-import port in Southern Sumatra, must take advantage of the opportunity from the abundant capacity of Tanjung Priok, and even create services that compete with Bojonegara and Palembang Ports to become alternative options for the flow of goods to and from other countries.

In the economic sector, Bandar Lampung City has a great opportunity to establish itself as a center for trade and services on the South Sumatra scale. In line with export-import and inter-island trade activities, Bandar Lampung has the opportunity to become the center of trade in agricultural and industrial products from southern Sumatra as well as those imported from outside regions. At this time, Hinterland Bandar Lampung has acted as 
the supplier of the results of plantations, livestock and fisheries that were seeded, especially the commodities of sugar, coffee, pepper, coconut, fresh meat and shrimp. This is also evident from the tendency of the growth of agro-industry activities towards the mainstay agro industry centers on the island of Sumatra. This provides an opportunity for Bandar Lampung to provide trade facilities and business services such as banking, offices and so on.

Another prospective sector for Bandar Lampung is tourism, both in order to support tourism development in southern Sumatra and to utilize the potential of the natural beauty of Bandar Lampung. The development of coastal and sea tourism objects and hills in the city of Bandar Lampung creates an attraction for foreign and domestic tourists. The completeness that can be prepared by Bandar Lampung is the provision of infrastructure and tourism services such as hospitality, travel agents, banking, and other supporting infrastructures.

Based on the Lampung Province Regional Regulation Number 1 of 2010 concerning the Regional Spatial Planning (RTRW) of Lampung Province in 2009-2029 the regions were used as an area of cooperation between regencies or cities as regional development. The area of cooperation that is seen from the potential and regional economic structure can be utilized for efforts to equalize development in a region. Based on this, Bandar Lampung is designated as the center of growth. It is expected that with the central growth area, Bandar Lampung City can protect and provide spread effects to the hinterland.

Furthermore, according to Article 14 paragraph (1), government affairs which are the authority of the Regency / City Government are as follows:

1. Development planning and control

2. Planning, utilization and supervision of spatial planning

3. Implementation of public order and peace of society

4. Provision of public facilities and infrastructure Handling the health sector

5. Organizing education

6. Overcoming social problems

7. Employment services

8. Facilitating the development of cooperatives, small and medium enterprises

9. Environmental control

10. Land services

11. Population services and civil records

12. Government general administration services

13. Investment administration services

14. Organizing other basic services

15. Other mandatory matters mandated by legislation.

Based on the above provisions, it is clear that the policy of the city government in overcoming traffic congestion is the implementation of its authority, especially in the fields of planning, utilization and supervision of spatial planning and the provision of public facilities and infrastructure.

On the other hand the problem arises from the City of Bandar Lampung facing its challenges as a hinterland city for Jakarta and the surrounding cities. The problems faced by the City of Bandar Lampung, one of which is traffic congestion due to a variety of complex, multidimensional and interconnected factors, so that discussions on this issue cannot be carried out separately and partially but carried out in full and thoroughly. Various factors causing traffic congestion in Bandar Lampung include:

1. Concentration of various activities in the city center

2. Almost the same time of activity in the city

3. The number of public transport and private vehicles

4. The number of street vendors (PKL) who sell on the sidewalk along the city protocol road.

5. Low discipline of road users

6. Number of shadow terminals along the edge of the road

7. Crossing / railroad tracks

Prospective development opportunities also bring prerequisites for the expected city life to be achieved. The first is the restructuring of the trend of physical development, and the second is the creation of a climate conducive to the development of the city of Bandar Lampung. In addition to providing infrastructure and facilities to support economic activities; preparation of policies, regulations, and development programs towards stabilizing Bandar Lampung in utilizing existing economic opportunities, human resources must be prepared to support the economic development.

\section{The Traffic Policy Model for the City of Hinterland in Indonesia}

In providing an analysis of the traffic policy model, it is necessary to identify problems related to traffic. The problems that exist in the first identification are the low level of community participation in traffic control, the lack of public knowledge about the prevailing traffic regulations in Indonesia, and the lack of public awareness 
to find out traffic regulations. The second identification is the high number of traffic accidents both at traffic light intersections and on highways, the safety of motorists, and pedestrians who become threatened. Furthermore, as a third identification, namely traffic congestion due to people who are reluctant to walk and the habit of violating ordinary traffic rules which then becomes a culture of breaking the rules.

Actually, theincreases in non-motorized transport improve traffic safety incities. A research (employing data from developed cities) has shown that the likelihood of collision between a pedestrian or cyclist and a motor vehicle is inversely related to the amount of foot or bicycle traffic (P. Jacobsen, 2003). Therefore, in mediumsize developing cities, investment and support for walking and cycling are paramount (H. Dimitrio; R. Gakenheimer, 2011). Various recent examples of improvements and innovation in non-motorized transport policy in developing countries can be identified. For example, Chinese cities have rapidly transitioned from human-powered bicycles and gasoline-powered scooters to electric bicycles. Improvements in e-bike technology, growing incomes, and falling e-bike prices, as well as government policies including e-bike national standards and safety regulation, local sale restrictions for gasoline scooters, and banning of gasoline vehicles from city centers have encouraged this modal shift (J. Weinert; C. Ma; C. Cherry, 2007).

In democracies it is generally assumed that more public participation is better. In this mind the high level of participation shows that citizens follow and understand public problems and want to involve themselves in those activities. It also shows that the regime in question has a high level of legitimacy. Conversely, a low level of participation is generally regarded as a sign that it is not good because it can be interpreted that many citizens do not pay attention to state problems and show low legitimacy (Miriam Budiardjo, 2005).

From the literature review of community participation in developing countries, the concept of participation is widely interpreted. Regarding the meaning of the concept of participation, Schneider argues (Hartmut Schneider \& Marie-Helene Libercier, 1995) :

"Although the need for more popular participation in the development process generally acknowledged, the concept of participation has been given different meanings in different situations. Increasingly, however, it is accepted that genuine participation should embody some form of empowerment of the population especially participation in decision making. Genuine participation means that people should be involved throughout project or programmed cycle, from the design stage through monitoring evaluation".

Community involvement in the implementation of regional governance is a manifestation of the nation's relationship and agreement to the values of democracy and political ethics that place the people as a source of power and sovereignty. Although the frequency, relevance, and intensity of community members are not the same as participating, community participation can be seen as one of the basic and most logical benchmarks to assess the success of implementing a policy. Community participation in Act Number 23 of 2014 concerning Regional Government has been guaranteed in Article 354. To encourage public participation, based on Article 354 paragraph (2) the Regional Government does the following:

a. Delivering information about the implementation of regional government to the community;

b. Encouraging groups and community organizations to play an active role in the implementation of Regional Government through community capacity building support;

c. Developing institutionalization and decision-making mechanisms that enable groups and community organizations to be involved effectively; and/or

d. Doing other activities in accordance with statutory provisions.

To be able to encourage community participation, citizens must be guaranteed access to information about various matters related to the administration of government activities and public services because information is the main raw material for the public policy process. So far, access to information about government activities is still very limited. Moreover, various procedures and provisions regarding policy processes that prevent citizens and stakeholders from becoming involved in the policy process in the regions should be encouraged to become more open, accessible and close to the community so that the obstacles to participation become lower.

In connection with these three identification problems, we initiated this analysis of traffic policy in Bandar Lampung City based on principles that we categorized as human and social value based policies. The description of the values that should be a reference to the traffic policy is:

1. Transparent principle is openness in the implementation of Traffic to the wider community in obtaining correct, clear and honest information so that the community has the opportunity to participate in the development of Traffic.

2. The accountable principle is the implementation of Traffic that can be accounted for.

3. Continuous principle is guaranteeing the quality of environmental functions through regulation of vehicle-worthy technical requirements, general development plans and development of Traffic Networks.

4. The participatory principle is the regulation of community participation in the policy-making process, oversight of the implementation of policies, handling accidents, and reporting on events related to 
Traffic.

5. Useful principles are all traffic management activities that can provide maximum added value in order to realize community welfare.

6. The principle of efficiency and effectiveness is service in the implementation of traffic carried out by each coach at the level of government in an efficient and effective manner.

7. Balanced principle is the implementation of Traffic which must be carried out on the basis of a balance between facilities and infrastructure and fulfillment of the rights and obligations of Service Users and organizers.

8. Integrated basis is the implementation of Traffic service which is done by prioritizing the compatibility and interdependence of authority and responsibility between the institutions of the builder.

9. Self-fundamental is an effort to organize traffic through the development and empowerment of national resources.

According to the theory, the policy will be effectively implemented if the policy has been adapted to the needs of the city community. In the research that has been carried out this policy uses a theoretical basis from Lawrence M. Friedman. He argued that the effectiveness and success of legal policies depends on three elements of the legal system, namely the structure of law, substance of the law, and legal culture. Legal structure is related to law enforcement officials, the legal substance is that includes the legislation and legal culture is the living law that is adopted in a society. About legal structure Friedman explains (Lawrence M. Friedman, 1984),

"To begin with, the legal system has the structure of a legal system consist of elements of this kind: the number and size of courts; their jurisdiction ...Structure also means how the legislature is organized ... what procedures the police department follow, and so on. Structure, in way, is a kind of cross section of the legal system ... a kind of still photograph, with freezes the action."

As for the legal culture, Friedman argues:

"The third component of legal system is of legal culture. By this we mean people's attitudes toward law and legal system, their belief ...in other word, are the culmination of social thought and social force which determines how law is used, avoided, or abused".

Legal culture concerns the legal culture which is the human attitude (including the legal culture of the law enforcers) towards the law and legal system. No matter how well structuring the legal structure to carry out the stipulated legal rules and as good as any quality of legal substance made if without the support of legal culture by the people involved in the system and the community then law enforcement will not run effectively.

Legal culture is the rationale for the formulation of the form of a policy model based on the character of society. As conveyed by Munir Fuady, law as a tool to change society or social engineering is nothing but ideas that the law wants to realize. To ensure the achievement of legal functions as a better engineering society, it is not only required the availability of law in terms of rules or regulations, but also a guarantee for the realization of the rule of law into legal practice, or in other words, a guarantee of good law enforcement (Munir Fuady, 2013).

Whereas according to Christine S.T. Kansil, Transportation plays a role as a supporter, driver and activator for the growth of a region, so that transportation services are needed that are compatible with the level of traffic needs and transportation services that fulfill ideal values such as orderliness, regularity, smoothness, safety, and security. To achieve these ideal values, there is a demand for a structured, integrated, organized, systematic and structured management and management system of transportation traffic in the interests, justice and welfare of the people in the regions (provinces, districts/cities) concerned. (Christine S.T. Kansil, 1995).

Obtaining policy goals and direction with human social values is the goal and direction of policies based on community participation and awareness. With the output of the traffic policy model seen in a legal and social perspective, it is an idea of a form of policy based on social values of society that is referring to principles (participatory, useful, efficient and effective, balanced, integrated, independent, sustainable, and transparent). Our idea regarding the human and social value traffic policy model provides hope. The aim of this research is to make Bandar Lampung City the City of Ethics, which can be an example of traffic order that is supported by encouragement of awareness and participation of the people in complying with all traffic policies and regulations in Bandar Lampung City.

The policy to anticipate this traffic congestion by the City Government of Bandar Lampung was poured into a work program by paying attention to various aspects related to the policy. Basically, this policy is directed at creating traffic smoothness and order both for the present and for the future. Apart from having to be patterned, integrated, organized, and systematic and based on interests, justice and people's welfare, it must also provide space for public involvement in the form of participation of all components of the wider community.

\section{Conclusion}

In overcoming congestion in a densely populated city in Bandar Lampung, several policies need to be implemented. In this study we made a policy where the City of Bandar Lampung as a hinterland city could implement the policy easily so that it resolved problems based on principles that we categorized as human and 
social value based policies, namely policies that are based on human and community values. The description of the traffic policy reference values includes: transparent principles; sustainable principle of guaranteeing the quality of environmental functions; participatory principle; useful principle; efficient and effective principle; balanced principle; integrated principles, and independent principles.

\section{References}

Budiardjo, Miriam. (2005). Dasar-dasar Ilmu Politik, Cet. Ke-27. Jakarta: PT. Gramedia Pustaka Utama.

Dimitriou, H. ; Gakerheimer, R (Eds). (2011). Urban Transport in the Developing World: A Handbook of Policy and Practice. London: Edward Elgar Publishing.

Firdaus, Dedi. (2006). Pola kemacetan lalu lintas di pusat Kota Bandar Lampung. Semarang: Program Studi Magister Teknik Pembangunan Wilayah dan Kota.

Friedman, Lawrence M. (1984). What is a Legal System” dalam American Law. New York: W.W Norton and Company.

Fuady, Munir. (2013). Teori-Teori Besar (Grand Theori) Dalam Hukum. Jakarta: Kencana Prenadamedia Group. Imelda. (2013). Identifikasi Pusat Pertumbuhan dan Daerah Hinterland Kota Palembang.

Jacobsen, P. (2003) Safety in Number: More Walkers and Bicyclists, Safer Walking and Bicycling. Inj. Prev, 9.

Kansil, Christine. S.T. (1995). Disiplin Berlalu Lintas di Jalan Raya. Jakarta: Penerbit Rineka Cipta.

Nazir, E., Nadeem, F. \& Véronneau, S. J Transp Secur (2016) 9: 161. https://doi.org/10.1007/s12198-016-01723.

Pojani, Dorina ; Stead, Dominic. (2015). Sustainable Urban Transport in the Developing World: Beyond Megacities. Sustainability.

Schneider, Hartmut \& Marie-Helene Libercier. (1995). Participatory Development From Advocacy to Action. Washington, D.C. : OECD Publication and Information Center.

Weinert, J.; Ma, C.; Cherry, C. (2007). The Transition to Electric Bikes in China: History and Key Reasons for Rapid Growth. Transportation.

Yunus, Hadi. (2005). Manajemen Kota Perspektif Spasial. Yogyakarta: Pustaka Pelajar. 